\title{
EVOLUTION OF KARAKORAM SEQUENCE, HUNZA VALLEY NE PAKISTAN: EVIDENCES FROM FIELD MAPPING AND MICRO-ANALYTICAL WORK
}

\author{
S. S. Baig1', C. Xue', Masroor Alam², Naeem Ullah', M. Alam³, S. A. Hussain4 \\ 1 Kunming University of Science and Technology, Kunming, 650093, P. R. China \\ 2 China university of Geo Sciences Beijing China \\ 3 Government Degree College Gilgit, Gilgit-Baltistan, Pakistan \\ 4 Chinese Academy of Sciences Qinghai China
}

\section{ABSTRACT}

The Karakoram metamorphic Complex (KMC) in the southern Karakoram block is one of the best examples of Barrovian type metamorphism that comprises numerous exhumed metapelite units where a series of low to high grade (green schist to sillimanite facie) rocks are exposed. This sequence shows a complex polyphase history of metamorphism and deformation which offer deeper understanding of collision orogeny. Karakoram metamorphic Complex contains metapelites, metacarbonates, meta-igneous and amphibolite layers, cross-cut by granite sheets in the northern part. This complex is bounded to the north by the Hunza plutonic unit which is the central portion of the massive east-west trending Karakoram axial batholith and to the southwest by the Main Karakoram thrust (MKT). In this contribution, we provide detail geological mapping, petrography, geochemistry and micro-analytical work using Electron Prob-micro analysis in the central Hunza Valley.

KEYWORDS: Karakoram metamorphic complex (KMC), metapelites, tectonothermal evolution, Magmatic gneiss.

${ }^{*}$ Corresponding author: (Email: sher.sultan.baig@gmail.com )

\section{INTRODUCTION}

Since detachment from the Gondwana supercontinent at c. $150 \mathrm{Ma}$, the Indo-Australian plate has drifted in northward anti-clockwise path, covering c. $5000 \mathrm{~km}$ before colliding with Asia [1]. Beforehand, the southern Asian margin was a passive margin in the Permian [5) which converted into an active continental margin in the Early to mid-Cretaceous $[3,4,5)$. First the closure of northern neo-Tethys at c. 102-75 $\mathrm{Ma}$ and then the southern, Kohistan block subsequently collided, accreted and indented into Asian plate margin at c. 50-55 Ma [2,3], with both events causing Barrovian-type metamorphism and magmatism on both plates. This collision resulted in crustal thickening, magmatism, polyphase metamorphism and deformation both along the northern margin of India (forming the Himalaya) and along the southern margin of Asia (forming the Hindu Kush, Karakoram and the Tibetan plateau) [6]. Oceanic and continental platform sediments of the Asian margin were subjected to low-pressure-hightemperature (LP-HT) andalusite-sillimanite grade metamorphism due to collision and emplacement of subduction related calc-alkaline granitoids of Karakoram axial batholith $[4,6]$. This sequence actually comprises of late-Paleozoic and earlyMesozoic sedimentary rocks that have been metamorphosed during and following collision.

Understanding the evolution of the continental crust during the orogenic cycle, and elucidating timing of metamorphism is fundamental but challenging issues. Karakoram metamorphic 
complex (KMC) exposed various metamorphic units, which provide data on rocks exist along strike at various depths in the southern Karakoram block today [5,7]. No focused work has been performed on paragneiss units. In this contribution, detailed geological mapping has been carried to KohistanKarakoram convergence and collision. In addition, we discussed the metamorphism, tectonic evolution and implications of timing of poly-phase metamorphism.

\section{GEOLOGICAL FRAMEWORK}

The northern terrane of Pakistan is composed of three major geological divisions. From north to south these divisions are 1) The Karakoram block 2) The Kohistan Island Arc and 3) The Indo-Pak plate. Main Karakoram Thrust (MKT) is the western extension of Indus Tsango suture zone (ITSZ) that separates Karakoram block to the north from Kohistan Island Arc to its south with a small back arc basin trap in between them Fig.1 [8,9]. The Karakoram block is equivalent to Qiangtang terrane of central south Tibet [9]. Within Karakoram block of Hunza valley, further three major zones are traversed, 2) a northern sedimentary zone, 2) a central Hunza pluton (Hunza plutonic unit; HPU) and 3) a southern metamorphic zone, Karakoram metamorphic complex (KMC) [10].

The northern sedimentary zone comprised of Paleozoic sedimentary carbonates and clastics extends from the Khunjerab pass south to the granite contact near the villages of Gulmit $[10,11]$. The central part of Karakoram comprised of subduction-related granitoids of the Hunza Plutonic Unit (HPU) (c. 95-105 Ma), which is the central part of huge east-west trending Karakoram Axial Batholith that divides sedimentary sequence to the north from metamorphic sequence (KMC) towards south [9]. Several sets of cross-cutting leucogranite dykes intrude both the southern part of Hunza pluton as well as the highest-grade metamorphic rocks (sillimanite-bearing gneisses) [6]. This early set of Hunza dykes have been dated at c. 50-52 Ma using U-Pb zircon geochronology [6]. Also of note is the Sumayar leucogranite, which is a post-metamorphic igneous body showing sharp intrusive contacts against the host rocks, and exhibits a small contact aureole in them $[6,7]$.

Metasedimentary rocks of Karakoram Metamorphic Complex (KMC) volumetrically dominate the southern margin of the Karakoram crustal block. KMC is the southernmost part of Karakoram block and the rock exposed here all considered being part of southern Asian margin prior to India-Asian collision [14]. With the initiation of subduction, magmatism and crustal thickening platform sedimentary protolith of KMC were subjected to low-pressure-high-temperature (LPHT) andulasite grade metamorphism and with crustal thickening medium-pressure hightempertaure (MP-HT) staurolite to sillimanite-grade barrovian metamorphism and partial melting $[8,9]$. Within the Karakoram Range, rocks exposed between Main Karakoram Thrust (MKT) to the south and the Karakoram Batholith to the north are collectively called the KMC Fig. 2 [12,13]. 


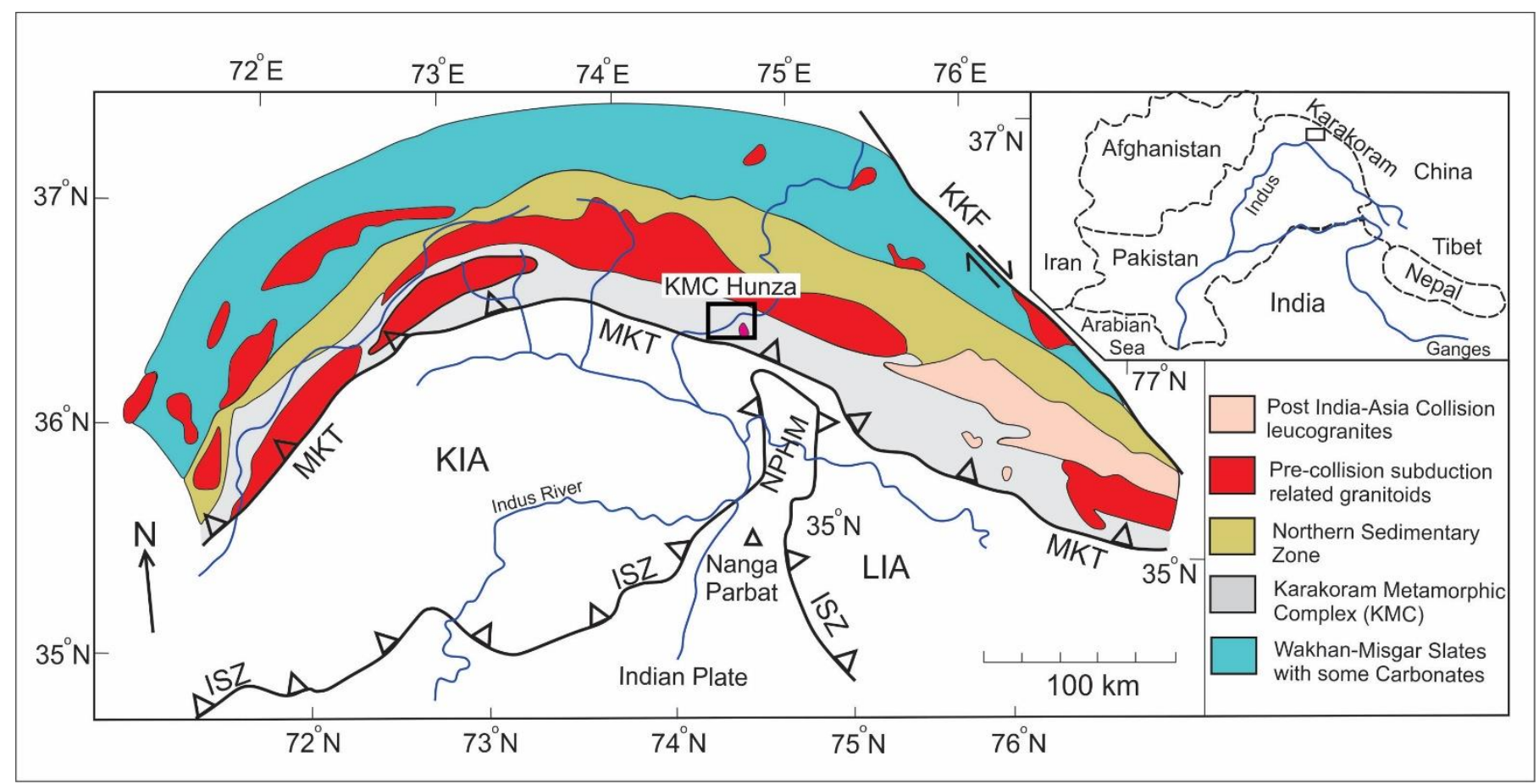

Figure. 1 Schematic geological map of north Pakistan showing the location of the Hunza valley (black rectangle) within the Karakoram Range. (modified after Fraser et al., 2001).

KMC hosts metapelitic (schists and gneisses) massive marbles and lens/layers of amphibolite with interlayered migmatites, and cut by granite sheets in the sillimanite zone $[1,3,10,12,14]$. At few places in extreme north of KMC in upper sillimanite zone migmatites with distinct migmatites with layers of leucosome $(1 \mathrm{~cm}-28 \mathrm{~cm})$ and melanosome (1 cm-2m) are exposed. These migmatite are sedimentary

derived high temperature melts (anatectic granites), and both leucosomes and melanosome have garnet and biotite schlieren. A series of NE dipping thrust faults control the geology and structure of the central Hunza valley, which juxtapose various tectono-stratigraphic units against each other resulting in a general increase in metamorphic grade and age northwards. From north to south, these are the Karimabad thrust, the
Aliabad thrust, the Murtazabad Thrust, the Chikas thrust, the North Nasirabad Thrust, the South Nasirabad thrust, and the Main Karakoram thrust (MKT). In the south Main Karakoram thrust (MKT) or Northern suture zone (NSZ) or Shyok suture zone (SSZ) divides Karakoram block to the north from Kohistan island arc towards south $[6,7]$. 


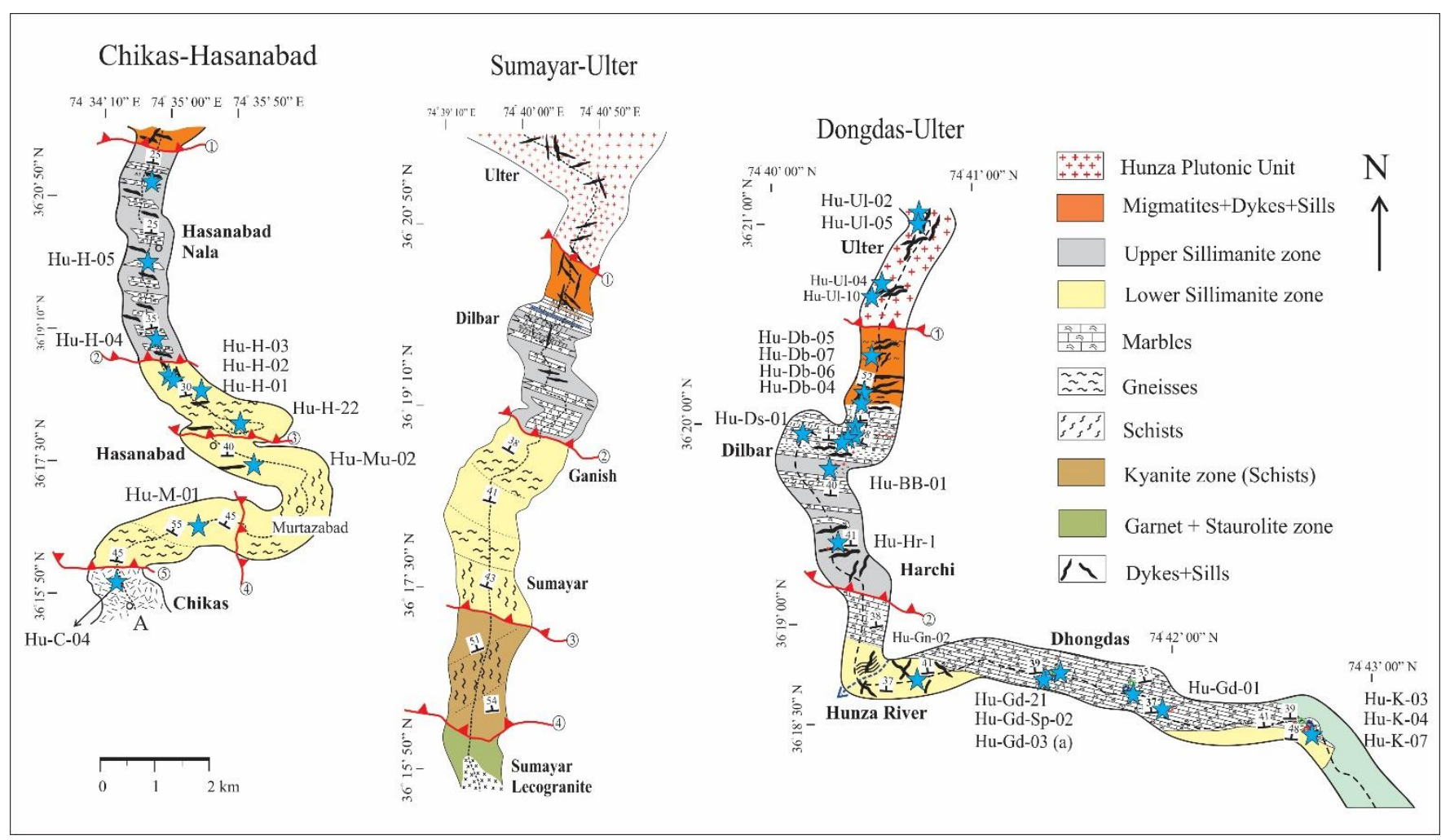

Figure. 2 Lithological comparison of three crossections and distribution of major rock units (Left). Chikas-Hasanabad (Middle). Sumayar-Ulter and (Right). Dongdas-Ulter.

\section{ANALYTICAL METHODS}

To determine characteristic mineral assemblages, mineral reactions and microstructural evidence for the sequence of deformation, metamorphism and tectonic setting of formation, thin sections of each sample were examined using an Olympus BX51-P electron microscope at Kunming University. Wholerock geochemical analyses of all lithologies collected from the KMC were performed at the Guiyang Institute of Geochemistry to acquire major element concentrations, whereas trace elements and rare earth elements (REE) were determined by Lithium Metaborate/Tetraborate Fusion-ICP and Lithium Metaborate/ Tetraborate Fusion-ICP/MS.

Electron microprobe analyses were carried out using a JEOL JXA-8100 (Oxford Inca) microprobe housed at Institute of geology Chines Academy of Geological Sciences (IGCAS) Beijing, operating with an accelerating voltage of $15 \mathrm{kV}$, and a beam current of $2 \times 10^{-8} \mathrm{~A} / 10 \mathrm{sec}$ which is equipped with four wavelength-dispersive spectrometers.. Microprobe is equipped with four wavelengthdispersive spectrometers (EDS) with accelerating voltage of $20 \mathrm{KV}$ and current $1.5 \times 10^{-9} \mathrm{~A} / \mathrm{sec}$. Natural and synthetic silicates and oxides were used for calibration. Representative mineral analyses are listed in Table 1.

\section{SAMPLES COLLECTION AND PETROGRAPHY}

A total of 14 samples were collected from the Hunza valley during field investigation, mostly from the upper sillimanite zone surrounding Hasanabad, Aliabad, and Karimabad (Figure. 2). Out of these, a subset of 10 samples were selected for further EPMA and microanalytical work presented herein Fig 3. 


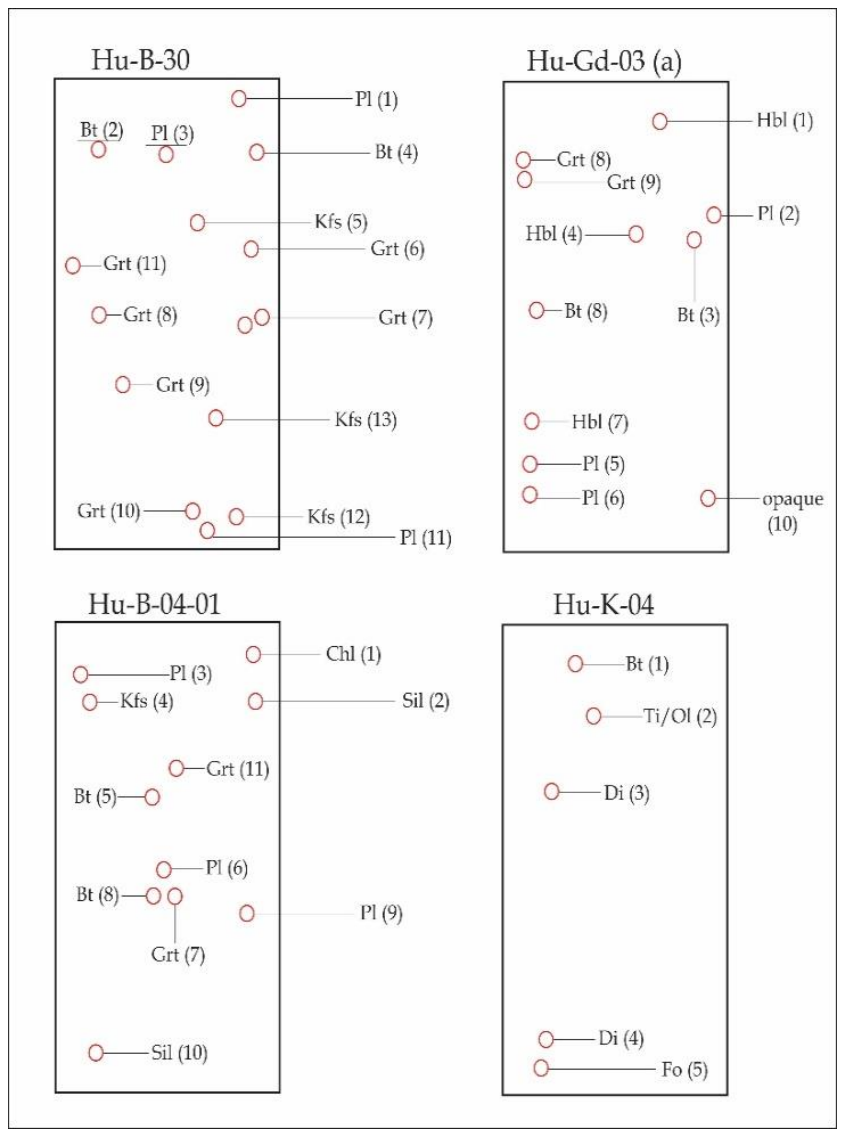

Figure. 3 Diagrammatic thin sections with spot selection points for EPMA.

Metapelitic members typically contain garnet (Grt), biotite (Bt), quartz (Qtz), plagioclase (PI), Kfeldspar (Kfs), and sillimanite (Sil), alongside accessory minerals apatite (Ap), zircon (Zrn) and ilmenite (ilm). Sample Hu-Db-02, containing garnet porphyroblasts with diameter ranged between $(1.5$ - $5.5 \mathrm{~mm})$, which are wrapped by a continuous foliation defined by biotite, sillimanite, quartz. Matrix minerals include plagioclase, Kfeldspar, graphite and quartz.

These representative samples comprised six metapelites and four migmatites (four melanosome and two leucosome segregations). Thin sections of each studied sample were examined to determine characteristic mineral assemblages and microstructural evidence for the sequence of deformation events. The detail mineral assemblages are mention in petrological section below. Mineral abbreviations given below follow the guidelines of Kretz (1983). Samples are show in Table 1. In almost all metapelites we observed ribbons of quartz and biotite that wrap the matrix (Fig. 4). Garnet porphyroblasts in metapelite (Hu-Gd-10) are up to $8.5 \mathrm{~mm}$ in diameter show well defined core-rim relationships, differentiated texturally by inclusion patterns. Broad cores show very little chemical variation and contain biotite, muscovite, quartz, plagioclase (Fig. 4).
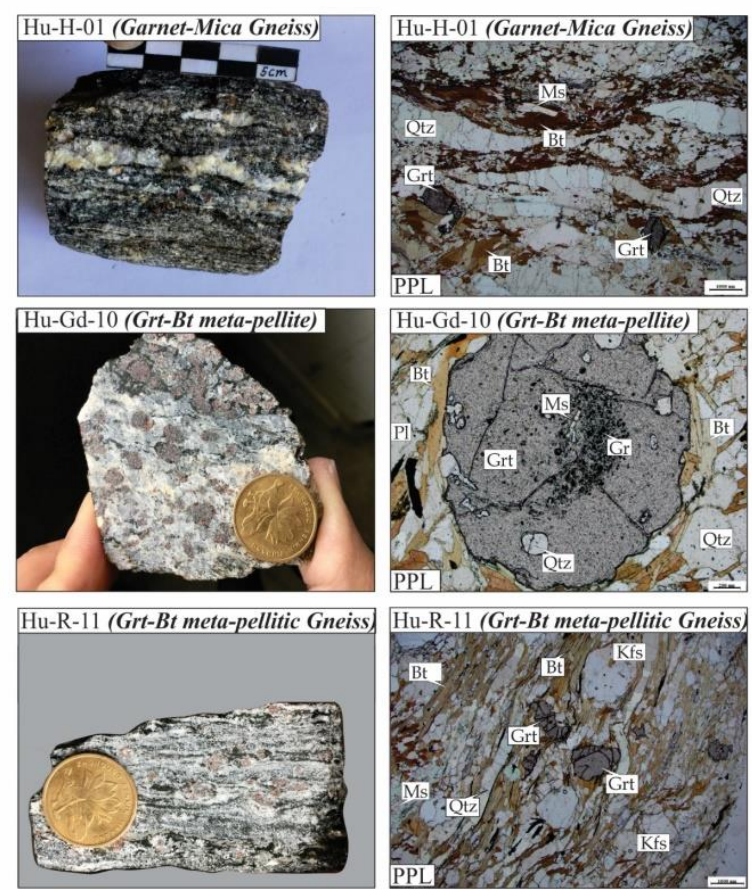

Figure. 4 Representative hand samples and thin section from metapelite sample in Karakoram metamorphic complex (KMC).

Both samples are coarse-grained, foliated metapelites of the upper-sillimanite gnesiss, exposed at Dibar and Dhondas valley and have almost similar mineralogies and textural characteristics.

Sedimentary derived high temperature melts (migmatites) with both leucosomes and melanosome are exposed in the upper sillimanite 
zone, north of Karimabad. Relatively massif melanosome forms (1 cm to $2 \mathrm{~m}$ ) thick beds contain mineral assemblages includes garnet (Grt), biotite (Bt), K-feldspar (Kfs), quartz (Qtz), plagioclase (PI), sillimanite (Sil) and small amounts of chlorite (Chl) and accessory muscovite (Ms). In melanosome part coarse garnet, biotite flakes and quartzo-felspathic boudins are easily discernable with occasional concentration of sillimanite. Abundance of biotite in this rock is notable which form distinct foliation in the rocks. Leucosome are intensively foliated with large garnet porphyroblasts and even the inclusions in garnet are highly oriented and aligned along the foliation. The leucosome unit contains variety of minerals including garnet (Grt), sillimanite (Sil), and chlorite (Chl) alternating with quartzo-feldspathic layer ranged in thickness from $1-26$ centimeters.

\section{RESULTS}

\subsection{Geochemistry}

The metapelites exhibited moderate $\mathrm{SiO}_{2}(57.42 \%$ and $64.90 \%), \mathrm{MgO}$ (1.24\% and $2.74 \%), \mathrm{Na}_{2} \mathrm{O}(2.81 \%$ and $3.24 \%)$, and $\mathrm{K}_{2} \mathrm{O}(1.94 \%$ and $3.85 \%)$ and $\mathrm{CaO}$ ( $1.46 \%$ and $1.96 \%$ ) contents, but high $\mathrm{Al}_{2} \mathrm{O}_{3}(16.05 \%$ and $18.02 \%)$ and $\mathrm{FeO}_{\mathrm{T}}(6.38 \%$ and $14.71 \%$ ) contents. On a chondrite diagram the trace-element contents are minor enriched in light rare earth element (LREE) except Hu-Gd-11 which shows unUsually higher HREE with observable Eu anomaly Fig. 5). On primitive-mantle diagram, $U$ and Dy show enrichment pattern while Sr, P and Ti reflects significant negative anomaly.

\section{DISCUSSION}

\subsection{Tectonic evolution of the Hunza Karakoram}

Plate convergence at island arcs, continental arcs, or continent-continent collision zones induces metamorphism, magmatism, deformation, and crustal thickening in the over-riding plate [13]. The long-lived metamorphism, coeval magmatism and anatexis can be interpreted as a result of the partial melting of the thickening crust related to the collision (14). As a result of India-Asia collision, Andean continental margin with multiple orogenparallel blocks from in east-west trend. During and following collision and compression, the sediments on southern margin of Asian basin
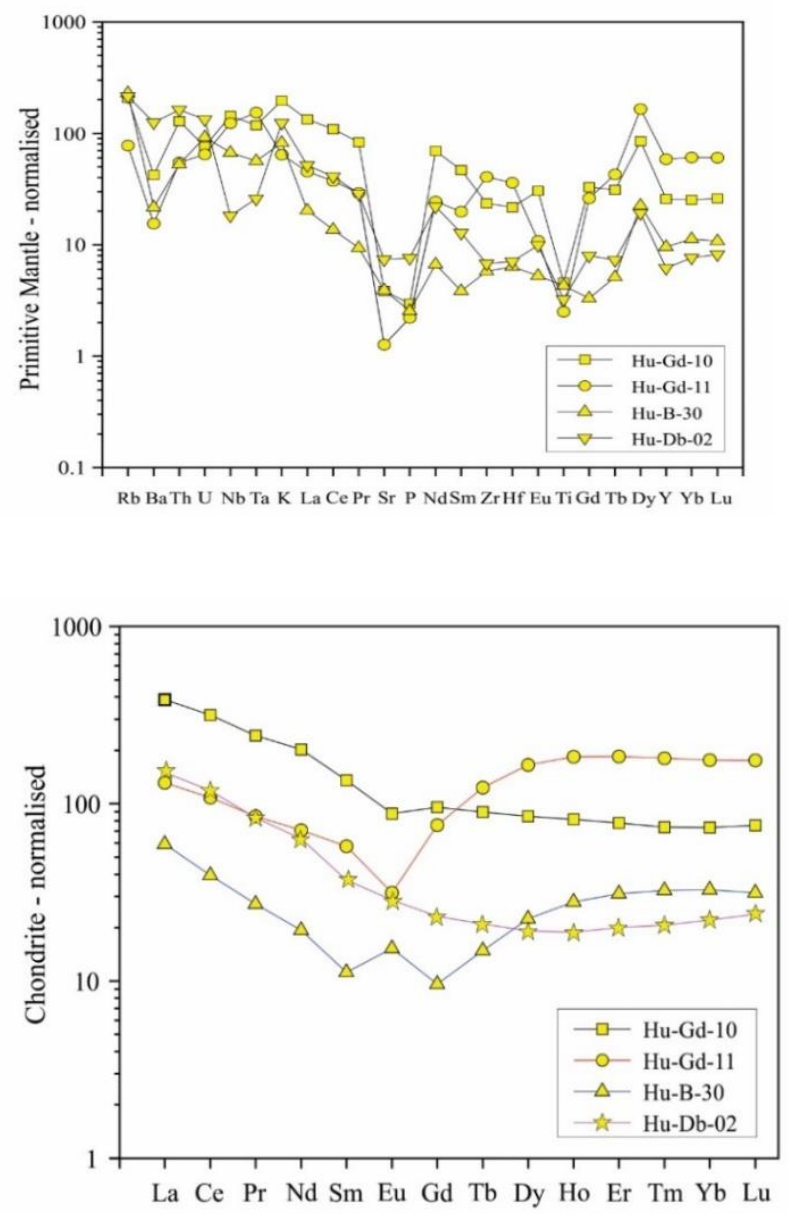

Figure. 5 Condrite normalized and primitive normalized diagrams for metapelites. (Normalized values from Sun and Mcdonough 1989).

metamorphosed. The partial melting of metapelites resulted in formation of sedimentary derived/S-type in situ migmatites with distinct layers of leucosomes and melanosomes, with the former containing garnet and biotite schlieren. Garnet porphyroblasts are abundant, and greencolored aggregates of chlorite pseudomorph other peritectic phases, which we 
Table 1. Representative samples and mineral assemblages from KMC.

\begin{tabular}{|c|c|c|c|c|c|}
\hline S.No & Sample \# & Locality & GPS & Lithology & Mineral Assemblage \\
\hline 1 & Hu-B-04-01 & Karimabad & $\begin{array}{l}N: 362030.2 \\
E: 743900.8\end{array}$ & Leucosome & $\mathrm{Grt}+\mathrm{Bt}+\mathrm{Qtz}+\mathrm{Ms}+\mathrm{Sil}+\mathrm{Ch}+\mathrm{Kfs}+\mathrm{Di}+$ Tre \\
\hline 2 & Hu-B-04-03 & Karimabad & $\begin{array}{l}N: 362030.1 \\
E: 743901.5\end{array}$ & Grt-Bt Gneiss & $\mathrm{Qtz}+\mathrm{Grt}+\mathrm{Pl}+\mathrm{Bt}+\mathrm{Kfs}+\mathrm{Ms}$ \\
\hline 3 & Hu-B-04-04 & Karimabad & $\begin{array}{l}\text { N: } 362029.1 \\
E: 743849.1\end{array}$ & Qtz-Bt Gneiss & $\mathrm{Qtz}+\mathrm{Bt}+\mathrm{Ms}+\mathrm{Pl}+\mathrm{Grt}$ \\
\hline 4 & $\mathrm{Hu}-\mathrm{B}-30$ & Karimabad & 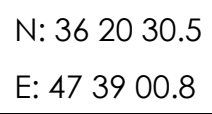 & Melanosome & $\mathrm{Bt}+\mathrm{Qtz}+\mathrm{Pl}+\mathrm{Grt}+\mathrm{Sil}+\mathrm{Kfs}+\mathrm{Ms}$ \\
\hline 5 & Hu-B-33 & Karimabad & $\begin{array}{l}N: 362029.3 \\
E: 473901.2\end{array}$ & Leucosome & $\mathrm{Bt}+\mathrm{Qtz}+\mathrm{Pl}+\mathrm{Grt}+\mathrm{Kfs}+\mathrm{Sil}+\mathrm{Tre}+\mathrm{Di}$ \\
\hline 7 & $\mathrm{Hu}-\mathrm{Db}-16$ & $\begin{array}{l}\text { Murko, } \\
\text { Karimabad }\end{array}$ & $\begin{array}{l}\text { N: } 362013.1 \\
E: 744024.8\end{array}$ & Grt-Schist & $\mathrm{Grt}+\mathrm{Sil}+\mathrm{Qtz}+\mathrm{Pl}+\mathrm{Bt}+\mathrm{Ms}$ \\
\hline 8 & Hu-Gd-10 & Dhongdas & $\begin{array}{l}N: 361832.2 \\
E: 744119.9\end{array}$ & meta-pellite & $\mathrm{Bt}+\mathrm{Grt}+\mathrm{Qtz}+\mathrm{Ms}+\mathrm{Pl}+\mathrm{Kfs}$ \\
\hline 9 & Hu-Gd-11 & Dhongdas & $\begin{array}{l}\text { N: } 361835.6 \\
\text { E: } 744141.4\end{array}$ & meta-pellite & $\mathrm{Qtz}+\mathrm{Grt}+\mathrm{B} \dagger+\mathrm{Ms}+\mathrm{Ch}$ \\
\hline 10 & $\mathrm{Hu}-\mathrm{H}-0 \mathrm{O}$ & Hasanabad & $\begin{array}{l}\text { N: } 361807.2 \\
E: 743527.9\end{array}$ & $\begin{array}{l}\text { two-mica } \\
\text { Gneiss }\end{array}$ & $\mathrm{Qtz}+\mathrm{Bt}+\mathrm{Grt}+\mathrm{Pl}+\mathrm{Kfs}+\mathrm{Ms}$ \\
\hline 11 & $\mathrm{Hu}-\mathrm{HB}-02$ (a) & Karimabad & $\begin{array}{l}\text { N: } 362001.4 \\
E: 744938.7\end{array}$ & Grt + Bt Gneiss & $\mathrm{B} t+\mathrm{Qtz}+\mathrm{Grt}+\mathrm{Pl}+\mathrm{Ms}$ \\
\hline 12 & $\mathrm{Hu}-\mathrm{HB}-02$ (a) & Karimabad & $\begin{array}{l}N: 362001.7 \\
E: 743933.2\end{array}$ & Qtz + B† Gneiss & $\mathrm{Qtz}+\mathrm{B} t+\mathrm{Ms}+\mathrm{Grt}+\mathrm{Pl}$ \\
\hline 13 & Hu-Jo-15 & Karimabad & $\begin{array}{l}\text { N: } 362022.2 \\
\text { E: } 743925.6\end{array}$ & Grt-Gneiss & $\mathrm{Qtz}+\mathrm{Bt}+\mathrm{Grt}+\mathrm{Kfs}+\mathrm{Ms}+\mathrm{Pl}+\mathrm{Sil}$ \\
\hline 14 & Hu-R-02 & Rahim Yari & $\begin{array}{l}N: 362000.1 \\
E: 744032.5\end{array}$ & Meta-pellite & $\mathrm{Qtz}+\mathrm{Bt}+\mathrm{Grt}+\mathrm{Pl}+\mathrm{Ms}+\mathrm{Sil}$ \\
\hline 15 & Hu-R-05 & Rahim Yari & $\begin{array}{l}N: 362005.1 \\
E: 744033.4\end{array}$ & Meta-pellite & $\mathrm{Qtz}+\mathrm{Pl}+\mathrm{B} \dagger+\mathrm{Ms}+\mathrm{Kfs}$ \\
\hline 16 & Hu-B-01 & Karimabad & $\begin{array}{l}N: 362026.2 \\
E: 743901.1\end{array}$ & Meta-pellite & $\mathrm{Qtz}+\mathrm{Bt}+\mathrm{Ms}+\mathrm{Pl}+\mathrm{Grt}+\mathrm{Kfs}$ \\
\hline 18 & $\mathrm{Hu}-\mathrm{Db}-08$ & $\begin{array}{l}\text { Dilbar, } \\
\text { Karimabad }\end{array}$ & $\begin{array}{l}N: 361958.6 \\
E: 744026.4\end{array}$ & Qtz + Bł Gneiss & $\mathrm{Qtz}+\mathrm{B} \dagger+\mathrm{Pl}+\mathrm{Ms}+\mathrm{Crd} ? ?$ \\
\hline
\end{tabular}


interpret to be kyanite, owing to the occurrence of relic cores with a light blue color. The Karakoram Range evolved into an uplifted This also reflects from whole rock geochemistry that the rocks contain high alumunia (16.05\% and $18.02 \%$ ) that reflects a shale or silty shale protolith for the metapelite unit. Magmatic precursors were likely intruded into the proto-KMC crust during northern plate subduction and closure of the Neo-Tethys, but before the KIA accreted to the Asian foreland. Sillimanite-grade metamorphism occurred south of the batholith during a high-temperature magmatic event, possibly associated with a large melt zone hidden at depth in the lower crust. This metamorphism is interpreted to be synmagmatism with that of major Mid-Cretaceous magmatism of Hunzaplutonic unit [7]. Field evidence proposes large-scale melting mostly occurred along the southern edge of the HPU and northern most part of KMC. This indicates the Karakoram metamorphic Complex recorded an upper amphibolite to lower granulite facies metamorphism.

\section{CONCLUSIONS}

Extensive field studies, mapping and laboratory work shows that Karakoram metamorphic complex undergone polyphase Barrovian type metamorphism. Combining the new data with data previously carried by other authors (6) allowed us to resolve the tectono-metamorphic history of the KMC on a regional scale and use these data for an overall analysis of the regional metamorphism in the realm of the Neotethys in southern Karakoram block. We conclude that

> The protoliths of Karakoram metamorphic complex (KMC) are mostly carbonates (limestone + dolomite + marls), pelites (shales and mud stones) and little psammites (impure sandstone).
> In almost all meta-pelites and migmatites garnet is floating inside the matrix.

> The high grade rocks (sillimanite grade) are in the north in Karimabad followed by well exposed migmatite restites

$>$ The presence of spinel within the garnet show deep metamorphism ( $>25 \mathrm{~km}$ within the crust).

> The meta-pelitic rocks in KMC are normal upper amphibolite facie rocks, barely entering into granulite facies.

> Upper amphibolite facie metamorphism of impure limestone has produced calc-silicate rocks and gems.

> During the late phase peak metamorphism the gneiss went partial melting of meta-pellites resulted in formation of leucosomes $(1-28 \mathrm{~cm})$ and melanosomes $(1 \mathrm{~cm}-2 \mathrm{~m})$.

\section{REFERENCES}

[1] Broughton, R. D., Windley, B. F., Jan, M. Q., Reaction isograds and P-T estimates in metasediments on the edge of the Karakorum Plate, Hunza, N. Pakistan. Geol. Bull. Univ. Peshawar, 1985, 18, 119-136.

[2] Burg, J.P., Bodinier, J.L., Chaudhry, S., Hussain, S., Dawood, H., Infra-arc mantle-crust transition and intra-arc mantle diapirs in the Kohistan Complex (Pakistani Himalaya): Petrostructural evidence. Terra Nova, (1998), 10, 74-80.

[3] Crawford, M. B., Searle, M. P., Collisionrelated granitoid magmatism and crustal structure of the Hunza Karakoram, North Pakistan. Geological Society, London, Special Publications, (1993), 74(1), 53-68.

[4] Debon, F., LeFort, P., Dautel, D., Sonet, J., Zimmerman, J., Granites of western Karakoram and northern Kohistan (Pakistan): A composite mid- Cretaceous to upper 
Cenozoic magmatism, Lithos, (1987), 20, 1940.

[5] Foster, G., Parrish, R.R., Horstwood, M.S.A., Chenery, S., Pyle, J., Gibson, H.D., The generation of prograde P-T-† points and paths; a textural, compositional and chronological study of metamorphic monazite. Earth and Planetary Science Letters, (2004), 228, 125-142.

[6] Fraser, J.E., Searle, M. P., Parrish, R. R., Noble, S. R., Chronology of deformation, metamorphism, and magmatism in the southern Karakoram Mountains. Geological Society of America Bulletin, (2001), 113(11), 1443-1455.

[7] Kazmi, A. H. \& Jan, M. Q., Geology and Tectonics of Pakistan. 544., Graphic Publishers, Karachi, Pakistan, (1997).

[8] Kretz, R., Symbols for rock-forming minerals. American mineralogist, 1983, 68, pp.277-279.

[9] LeFort, P., Michard, A., Sonet, J., Zimmermann, J.L., Petrography, geochemistry and geochronology of some samples from the Karakorum batholith (Northern Pakistan). In: Shams, F.A. (Eds.), Granites of Himalayas, Karakoram and Hindu Kush, (1983), 377-387.

[10] Palin, R. M., Searle, M. P., Waters, D. J., Horstwood, M. S. A., Parrish, R. R., Combined thermobarometry and geochronology of peraluminous metapelites from the Karakoram metamorphic complex, North Pakistan; New insight into the tectonothermal evolution of the Baltoro and Hunza Valley regions, J. Metamorphic Geol., (2012), 30, 793-820.

[11] Rehman, H.U., Seno, T., Yamamoto, H,. Khan, T., Timing of collision of the Kohistan-Ladakh Arc with India and Asia: Debate Island Arc, 2011, (2011) 20, p. 308-328.

[12] Rex, A.J., Searle, M.P., Crawford, M.B., Prior, D.J., Rex, D.C., Barnicoat, A., The geochemical and tectonic evolution of the central Karakoram, north Pakistan: Royal Society of London Philosophical Transactions, Ser., (1988), 326, 229-255.

[13] Rolland, Y., Carrio-Schaffhauser, E., Sheppard, S.M.F., Pecher, A., Esclauze, L., Metamorphic zoning and geodynamic evolution of an inverted crustal section (Karakorum margin, N Pakistan), evidence for two metamorphic events. International Journal of Earth Sciences, (2006), 95, 288-305.

[14] Searle, M. P., Khan, M. A., Fraser, J. E., Gough, S. J., Jan, M. Q., The tectonic evolution of the Kohistan-Karakoram collision belt along the Karakoram Highway transect, north Pakistan. Tectonics, (1999), 18(6), 929-949.

[15] Wallis, D., Phillips, R.J., Lloyd G.E., Evolution of the Eastern Karakoram Metamorphic Complex, Ladakh, NW India, and its relationship to magmatism and regional tectonics. Tectonophysics, (2014), 626 (2014) 41-52.

Received: 5 April 2020. Revised/Accepted: 3 June 2020. 